\title{
小型船舶における生体の立位姿勢動摇が エネルギー消費量に及ぼす影響
}

\author{
土井根 $\quad$ 礼音 $^{1} \cdot$ 宮脇 $\quad$ 富士夫 ${ }^{2} \cdot$ 瀬田 $\quad$ 広明 $^{3}$ ・坂牧 $\quad$ 孝規 $^{4}$ \\ Effects of Standing Postural Motions \\ on Human Energy Expenditures in a Small Marine Craft
}

\author{
Renon DOINE, Fujio MIYAWAKI, Hiroaki SETA and Takanori SAKAMAKI
}

\begin{abstract}
Crew member fatigue has been reported as one of the causes of marine accidents. In our previous study, it was found that human energy expenditure increased in a small marine craft because of the standing postural motions, such as motions of the head and the hip. The purpose of this study is to analyze the relationship between standing postural motions and energy expenditure, assuming that these motions are one of the causes of physical fatigue. Three orientation sensors capable of measuring linear accelerations and angular velocities were placed on the head and hip of each participant, and on the floor of the marine craft, to analyze the postural motions. Energy expenditure was measured using a calorimeter. The relationship between the standing postural motions and their energy expenditures was analyzed by multiple regression analysis of the following variables: energy expenditure, height, weight, and root mean square values of surge, sway, heave, roll, pitch and yaw motions at the head and hip of each participant, and on the floor of the marine craft. It was determined that weight and the pitch motions at the hip were especially affecting energy expenditure. The coefficient of determination was 0.71 . Thus, it was suggested that the pitch motions at the hip affect the energy expenditure in the small marine craft.
\end{abstract}

Keywords : labor and ergonomics, standing postural motions, energy expenditure, multiple regression analysis キーワード: 労働・人間工学、立位姿勢動摇、エネルギー消費量、重回帰分析

\section{1.はじめに}

船員の疲労は、船舶事故を引き起こすヒューマン エラーの原因の一つとして報告されている( ${ }^{(1)}$ 。疲労 は、肉体的負荷あるいは精神的負荷を連続して与え られたときにみられる肉体的および精神的パフォ ーマンスの低下現象と説明される ${ }^{(2)}$ 。船員の疲労を 低減するためには、船舶動摇が生体に与える影響を 解析し、船員の疲労原因を解明寸る必要がある。一
般に、生体の肉体的な負荷の大きさは、エネルギー 消費量や心拍数を指標として評価される。本研究で は、肉体的負荷を与えられることにより生じる疲労 （以下肉体的疲労）に焦点をあて、肉体的疲労の度 合いを評価する一つの指標として生体のエネルギ 一消費量を分析し、基礎研究として、船舶動摇によ り生じる生体の立位姿勢動摇とエネルギー消費量 の関係を導いた。

\footnotetext{
1 正会員 東京電機大学総合研究所（１１20-8551 東京都足立区千住旭町 5 番） doine@mail. dendai. ac. jp

2 非会員 東京電機大学理工学部理工学科電子工学系（干350-0394 埼玉県比企郡鳩山町石坂）

3 正会員 鳥羽商船高等専門学校商船学科（干517-8501 三重県鳥羽市池上町 1-1)

4 正会員 鳥羽商船高等専門学校制御情報工学科（干 517-8501 三重県鳥羽市池上町 1-1）
} 


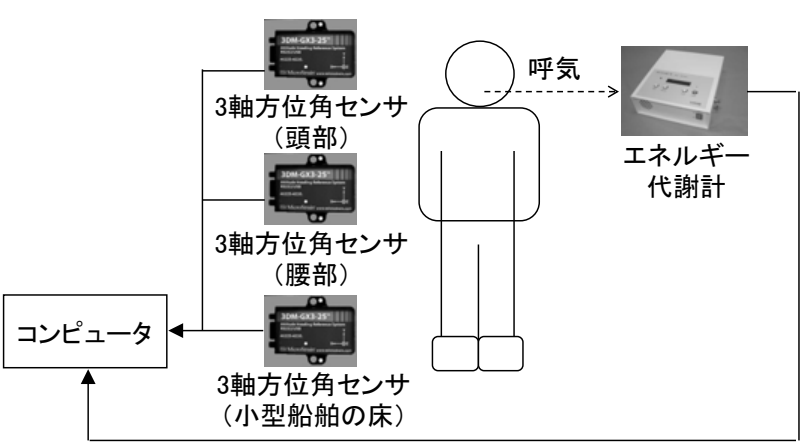

図 1 計測システムの概念図 ${ }^{(7)}$

表 13 軸方位角センサの仕様

\begin{tabular}{|c|c|c|}
\hline & 項目 & 仕様 \\
\hline \multirow{4}{*}{\multicolumn{2}{|c|}{ センサの出カ }} & 加速度 \\
\hline & & 角速度 \\
\hline & & 角度 \\
\hline & & 方位 \\
\hline \multirow{2}{*}{ 加速度 } & 測定範囲 & $\pm 5[\mathrm{G}]$ \\
\hline & バイアス安定性 & $\pm 0.005[\mathrm{G}]$ \\
\hline \multirow{2}{*}{ 角速度 } & 測定範囲 & $\pm 300[\mathrm{deg} / \mathrm{s}]$ \\
\hline & バイアス安定性 & $\pm 0.2[\mathrm{deg} / \mathrm{s}]$ \\
\hline \multirow{2}{*}{ 角度 } & 静的精度 & $\pm 0.5[\mathrm{deg}]$ \\
\hline & 動的精度 & $\pm 2.0[\mathrm{deg}]$ \\
\hline \multicolumn{2}{|c|}{ サンプリング周期 } & $0.01[\mathrm{~s}]$ \\
\hline \multicolumn{2}{|l|}{ 外寸 } & $44 \times 25 \times 11[\mathrm{~mm}]$ \\
\hline \multicolumn{2}{|c|}{ 重量 } & $11.5[\mathrm{~g}]$ \\
\hline \multicolumn{2}{|c|}{ インターフェース } & RS232C \\
\hline
\end{tabular}

船員の疲労に関する先行研究では、木村らが 3 隻 の船舶（(a) 全長 $27.5 \mathrm{~m}$ 、幅 $6.5 \mathrm{~m}$ 、(b) 全長 $56.0 \mathrm{~m}$ 、 幅 $11.1 \mathrm{~m}$ 、(c) 全長 $66.0 \mathrm{~m}$ 、幅 $12.6 \mathrm{~m}$ ) を使用し、ア ンケートにより評価した船員の疲労や船酔いの自 覚症状と船舶動摇、海況等の重回帰分析を行うこと により、船酔いや疲労に影響を及ぼす因子は船舶の 床の加速度と船舶の動摇周期であることを報告し ている ${ }^{(3)}$ 。また、船員のエネルギー消費量に関する 先行研究では、Breidah1 らが、2 隻の漁船 ( (a) 全長 $28.44 \mathrm{~m}$ 、幅 $8.20 \mathrm{~m} 、(\mathrm{~b})$ 全長 $23.50 \mathrm{~m}$ 、幅 $7.00 \mathrm{~m}$ ）を使 用し、船舶の床の回転角度とエネルギー消費量との 直線回帰分析を行うことにより、船舶動摇が船員の エネルギー消費量を増加させる可能性があること を報告している(4)。しかしながら、船員の疲労の評 価は、主観的なアンケート調査にとどまっており、 定量的な評価がなされていない。また、船舶動摇が 船員のエネルギー消費量を増加させる可能性があ ることが報告されているが、船員のエネルギー消費 量に影響を及ぼす動摇の解明には至っていない。
筆者らはこれまでに、船員の肉体的疲労の原因を 解明するために、生体が単一の剛体ではなく、関節 を有することから、船舶動摇により生じる生体の姿 勢維持動作 ${ }^{(5)}$ に着目し、生体の姿勢維持動作に伴う 立位姿勢動摇の計測、およびエネルギー消費量に基 づく運動負荷の解析を行った。これにより、船舶の 上下摇れ（heave）の実効值が $1.00 \mathrm{~m} / \mathrm{s}^{2}-1.39 \mathrm{~m} / \mathrm{s}^{2}$ の 範囲における生体の立位姿勢動摇に伴う運動負荷 は、陸上での 30 回/min の踏み台昇降運動の運動負 荷に相当することがわかった ${ }^{(6)}$ 。以上より、船員の 肉体的疲労の原因を解明寸るためには、基礎研究と して、船舶動摇により生じる生体の立位姿勢動摇と エネルギー消費量の関係を導くことが、解明に役立 つと考えた。

本研究は、小型船舶動摇により生じる立位姿勢動 摇が生体のエネルギー消費量に及ぼす影響の解明 を目的とし、重回帰分析を用いて生体のエネルギー 消費量に影響を及ぼす因子を解析した。重回帰分析 には、生体のエネルギー消費量、加速度・角速度の 実効值、生体の個体差を表す身長、体重を変数とし て使用した。

\section{2. 方法}

\section{1 実験}

\section{1.1 計測システム}

本研究の計測システムは、加速度・角速度を計測 する 3 軸方位角センサ、およびエネルギー消費量を 計測するエネルギー代謝計、コンピュータで構成さ れる(図 1)。3 軸方位角センサには、加速度センサ、 ジャイロセンサ、磁気センサが内蔵されている(表 1)。3 軸方位角センサを、小型船舶の床、生体の腰 部、頭部に設置し、計測インターバルを $0.01 \mathrm{~s}$ とし た。エネルギー消費量は、生体の呼吸量と $\mathrm{O}_{2}$ 濃度、 呼吸の頻度により算出され、10s 間のエネルギー消 費量を $10 \mathrm{~s}$ ごとに記録した。加速度・角速度計測の ための座標系を図 2 に示す。本研究では、3 軸方位 角センサの $\mathrm{x}$ 軸方向の加速度を前後摇れ (surge)、 $\mathrm{y}$ 軸方向の加速度を左右摇れ (sway)、 $\mathrm{z}$ 軸方向の加 速度を上下摇れ (heave)、x 軸まわりの角速度を横 摇れ (ro11)、y 軸まわりの角速度を縦摇れ (pitch)、 z 軸まわりの角速度を船首摇れ（yaw）と定義した。 本研究では、各計測部位の加速度・角速度を $\mathrm{x}$ 軸を 船首方向、y 軸を船舶の右側 (右舷)、 $\mathrm{z}$ 軸を地球の 中心の方向とする固定座標系上の加速度 ·角速度一 と座標変換し、各計測部位の動摇の比較を行った ${ }^{(8)}$ 。 


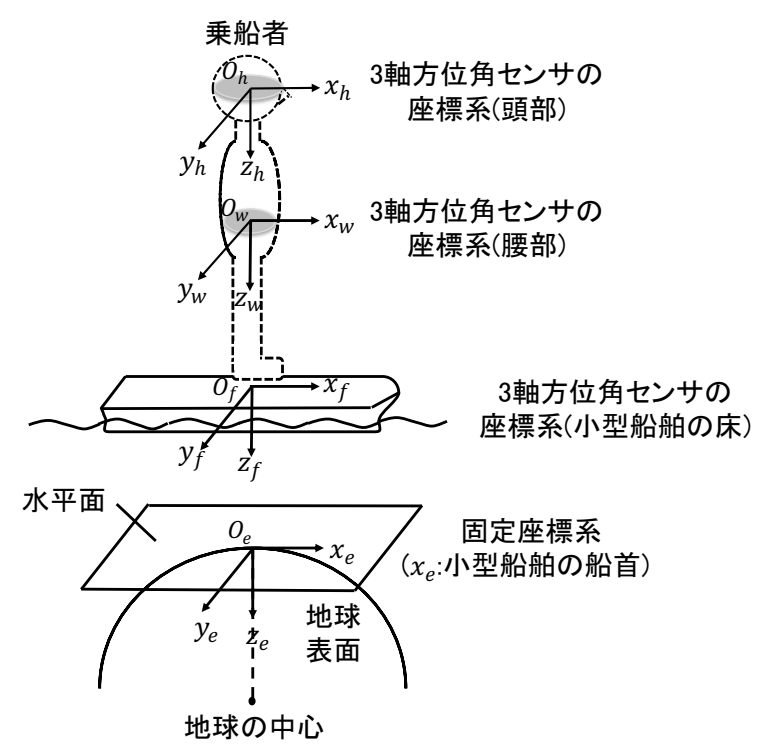

図 2 加速度 $\cdot$ 角速度の座標系 ${ }^{1(7)}$

\section{1.2 実験方法}

本実験は、鳥羽商船高等専門学校の生命倫理委員 会の承認のもとに行った。実験協力者には実験開始 前に実験内容の説明を行い、実験への参加について 同意を得た。また、食事や運動、睡眠によるエネル ギー消費量への影響を防ぐため、実験協力者には、 実験前日の夜は十分な睡眠をとり、実験開始前 4 時 間は水以外の飲食および激しい運動は控えるよう 指示した。データの計測は鳥羽商船高等専門学校が 所有する実習船「あさま」の船舶内で行った。小型 船舶の仕様は、総トン数 $14 \mathrm{t}$ 、全長 $12.5 \mathrm{~m}$ 、船幅 $4.2 \mathrm{~m}$ 、 全深さ $2.3 \mathrm{~m}$ 、喫水 $0.8 \mathrm{~m}$ 、最大速度 $28 \mathrm{knot}$ であり、 重心は、トランサム面から $4.5 \mathrm{~m}$ 、船底から $1.4 \mathrm{~m}$ に ある。小型船舶の速度は可能な限り一定とし、急な 変針は行わないようにした。視覚情報による影響を 最小限に抑えるために、船舶動摇の予測を可能とす る船外の風景が見えない船首側で実験を行った。

実験環境を図 3 に示す。実験は、実験協力者 15 名 に対し座位姿勢 15 分の後、立位姿勢 15 分をとらせ、 31 例のデータを収集した。座位姿勢での計測は、基 準となる生体のエネルギ一消費量を計測するため に行った。実験協力者の向きは、開眼状態で、船首 方向である船内の壁を正面とするように指示した。 さらに実験協力者には、座位姿勢時には、船舶内に 固定されたクッション性のある椅子に座り、立位姿 勢時には、両足を肩幅の位置で自然に立つよう指示 した (困 3)。立位姿勢の実験を行った船内の位置は、

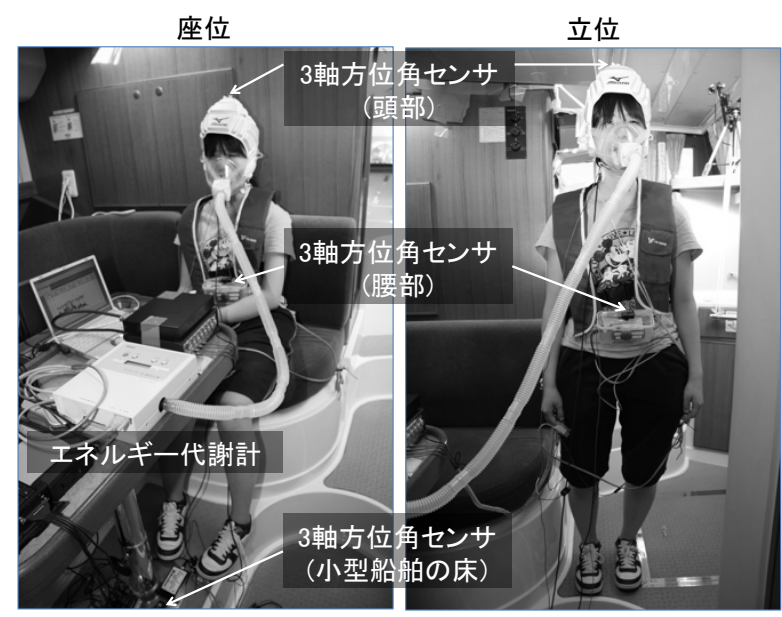

図 3 実験環境

トランサム面から約 $8.0 \mathrm{~m}$ 、船底から $0.7 \mathrm{~m}$ 、右舷から 約 $2.0 \mathrm{~m}$ である。安全を確保するため、実験協力者の 立ち位置は、とつさの摇れが発生したときにつかま ることのできる船内の壁の近くとした。

\section{2 エネルギ一消費量に影響を与える要因分析}

\section{2.1 重回帰モデル}

本研究では、重回帰モデルの従属変数をエネルギ 一消費量、独立変数を小型船舶の床、生体の腰部、 頭部の前後摇れ（surge）、左右摇れ（sway）、上下摇 れ (heave)、横摇れ (roll)、縦摇れ (pitch)、船首 摇れ（yaw）、個体差を考慮するための身長、体重の 20 変数とした。本研究で扱う重回帰モデル及び重回 帰分析により推定された重回帰モデルは式 (1)、式 (2) で表される ${ }^{(9)}$ 。式 (1) は従属変数 $Y$ を独立変数 $X_{i}(i=1, \cdots, 20)$ に対して回帰するモデルである。式中 の $\beta_{0}$ は、回帰面の $Y$ 切片を、 $\beta_{i}(i=1, \cdots, 20)$ は独立変数 $X_{i}$ に関する回帰面を、 $\varepsilon$ は誤差項を表す。式(2) は従 属変数 $Y$ と独立変数 $X_{i}$ の関係を推定した結果のモデ ルであり、 $\hat{Y}$ は従属変数 $Y$ の予測值を、 $b_{0}$ は回帰面の $\hat{Y}$ 切片を、 $b_{i}(\mathrm{i}=1, \cdots, 20)$ は偏回帰係数を表す。本研究 では共線性を防ぐために、互いに相関が高い $2 つ の$ 変数のうち、一方の変数を除くことで、重回帰モデ ルを構成する適切な独立変数の選択を行った。共線 性とは、互いに相関のない独立変数を使用すること が前提である重回帰分析において、互いに相関が高 い変数を使用することで、偏回帰係数の符号が本来 の現象とは逆になる等、正しい重回帰モデルを得ら れない現象である。従属変数に影響する独立変数の

\footnotetext{
${ }^{1} O$ は各座標系の中心を表している。各座標系の中心 $O$ と船体中心は、同じではない。
} 
抽出は、ステップワイズ法の一つである変数増減法 により行った。

本研究では、各独立変数間の測定単位の違いを考 慮するために、偏回帰係数を標準化した標準偏回帰 係数 $b_{i}{ }^{\prime}(i=1, \cdots, 20)$ を式 (3)により算出した ${ }^{(10)}$ 。式 (3) 中の $S_{X_{i}}$ は式(4)に示寸独立変数 $X_{i}$ の標準偏差を、 $S_{Y}$ は式(5)に示寸従属変数 $Y$ の標準偏差を表す。 $N$ は 従属変数 $Y$ おび独立変数 $X_{i}$ のサンプル数を表す。 標準偏回帰係数が大きい独立変数ほど、従属変数一 の影響力が大きいことを示している。

$$
\begin{aligned}
& Y=\beta_{0}+\beta_{1} X_{1}+\beta_{2} X_{2}+\cdots+\beta_{20} X_{20}+\varepsilon \\
& \hat{Y}=b_{0}+b_{1} X_{1}+b_{2} X_{2}+\cdots+b_{20} X_{20} \\
& b_{i}{ }^{\prime}=b_{i} \times \frac{S_{X_{i}}}{S_{Y}} \\
& S_{X_{i}}=\sqrt{\frac{1}{N} \sum_{m=0}^{N}\left(X_{i_{m}}-\bar{X}_{l}\right)^{2}} \\
& S_{Y}=\sqrt{\frac{1}{N} \sum_{m=0}^{N}\left(Y_{m}-\bar{Y}\right)^{2}}
\end{aligned}
$$

\section{2.2 従属変数と独立変数}

従属変数であるエネルギー消費量には、生体が運 動を始めてから応答するまでに時間遅れが生じる。 真家らは、生体にステップ入力（一定速度の歩行） を与えた際のエネルギー消費量の応答の時定数が、 男性が $1.38 \pm 0.28 \mathrm{~min}$ 、女性が $2.29 \pm 0.99 \mathrm{~min}$ で あったことを報告している ${ }^{(11)}$ 。本研究では、実験協 力者ごとに、エネルギー消費量が定常状態に達した と考えられる立位姿勢に移行してから 5 分後〜 15 分 後までの範囲でエネルギー消費量の平均值を算出 し、重回帰分析の従属変数とした。但し、立位姿勢 に移行してから 15 分経過前に、実験協力者が早め に座位姿勢に移行していたときのデータについて は除外した。

独立変数である各動摇の大きさは、式 (6) に示す 実効值 (RMS:Root Mean Square) により評価した ${ }^{(12)}$ 。 式(6)中の $f_{i}$ は、加速度又は角速度データを、 $N$ はデ 一タ数を表す。加速度・角速度の実効值は、エネル ギー消費量と同じ範囲で算出した。

$$
R M S=\sqrt{\frac{1}{N} \sum_{i=0}^{N-1}\left(f_{i}\right)^{2}}
$$

\section{2.3 重回帰モデルの評価}

本研究では、重回帰モデルの予測精度を評価する ために、従属変数と説明変数の相関係数を表す重相 関係数 $R$ と、重回帰モデルのあてはまりを表す自由 度調整済夕決定係数 $R^{2}$ を算出した。自由度調整済み 決定係数 $R^{2}$ は、式 (7)により算出される。式 (7) 中 のSSEは式（8）、SSTは式（9）により算出される。 $N$ は従属変数 $Y$ のサンプル数を、 $k$ は独立変数の数を、 $\hat{Y}$ は従属変数 $Y$ の予測值を、 $\bar{Y}$ は従属変数 $Y$ の平均值 を表す。

$$
\begin{aligned}
& R^{2}=1-\frac{\frac{S S E}{N-(k+1)}}{\frac{S S T}{N-1}} \\
& S S E=\sum_{i=1}^{N}\left(Y_{i}-\hat{Y}_{i}\right)^{2} \\
& S S T=\sum_{i=1}^{N}\left(Y_{i}-\bar{Y}\right)^{2}
\end{aligned}
$$

\section{3. 結果}

\section{1 重回帰モデルの決定}

本研究では、重回帰モデルを正しく推定するため に、収集した 31 例のデータに対し、外れ值の検定方 法の一つであるスミルノフの棄却検定を行い、3 例 の外れ值を除外した。従って本研究では、表 2 に示 す 15 名の実験協力者 $\mathrm{A} \sim 0$ の 28 例を対象に、重回 帰分析を行った。

表 2 の 28 例のデータについて、加速度・角速度 の実効值とエネルギー消費量の平均值の相関関係 を示したグラフを図 4〜図 6 に示す。図 6(d)〜 (f) に示した小型船舶の床の角速度は、生体の腰部と頭 部の角速度に比べて小さいため、図 4、5(d)〜 (f) よ りも横軸の縮尺を拡大している。また身長、体重と エネルギー消費量の平均值の相関関係を示したグ ラフを図 7、図 8 に示す。図 4 は実験協力者の頭部 で計測された加速度・角速度の実効值とエネルギー 消費量の平均值の相関関係を、図 5 は実験協力者の 腰部で計測された加速度・角速度の実効值とエネル ギー消費量の平均值の相関関係を、図 6 は小型船舶 の床で計測された加速度・角速度の実効值とエネル 
表 2 重回帰分析の対象とした実験協力者

\begin{tabular}{|c|c|c|c|c|c|}
\hline No. & $\begin{array}{c}\text { 実験 } \\
\text { 協力者 }\end{array}$ & 性別 & 年齢 & $\begin{array}{l}\text { 身長 } \\
{[\mathrm{cm}]}\end{array}$ & $\begin{array}{l}\text { 体重 } \\
{[\mathrm{kg}]}\end{array}$ \\
\hline 1 & A & 女性 & 19 & 149 & 39 \\
\hline 2 & A & 女性 & 19 & 149 & 39 \\
\hline 3 & B & 男性 & 19 & 170 & 75 \\
\hline 4 & B & 男性 & 19 & 170 & 75 \\
\hline 5 & $\mathrm{C}$ & 女性 & 18 & 149 & 53 \\
\hline 6 & $\mathrm{C}$ & 女性 & 18 & 149 & 53 \\
\hline 7 & $\mathrm{D}$ & 女性 & 23 & 150 & 48 \\
\hline 8 & D & 女性 & 23 & 150 & 48 \\
\hline 9 & D & 女性 & 23 & 150 & 48 \\
\hline 10 & $\mathrm{D}$ & 女性 & 24 & 150 & 48 \\
\hline 11 & E & 女性 & 18 & 162 & 57 \\
\hline 12 & $\mathrm{E}$ & 女性 & 18 & 162 & 57 \\
\hline 13 & $\mathrm{~F}$ & 男性 & 49 & 175 & 75 \\
\hline 14 & $\mathrm{~F}$ & 男性 & 49 & 175 & 75 \\
\hline 15 & $\mathrm{~F}$ & 男性 & 49 & 175 & 75 \\
\hline 16 & $\mathrm{~F}$ & 男性 & 49 & 175 & 75 \\
\hline 17 & $\mathrm{~F}$ & 男性 & 50 & 175 & 75 \\
\hline 18 & $\mathrm{G}$ & 女性 & 18 & 153 & 41 \\
\hline 19 & G & 女性 & 18 & 153 & 41 \\
\hline 20 & $\mathrm{H}$ & 男性 & 19 & 168 & 53 \\
\hline 21 & $\mathrm{I}$ & 女性 & 18 & 151 & 45 \\
\hline 22 & $\mathrm{~J}$ & 女性 & 18 & 153 & 48 \\
\hline 23 & $\mathrm{~J}$ & 女性 & 18 & 153 & 48 \\
\hline 24 & $\mathrm{~K}$ & 女性 & 19 & 156 & 54 \\
\hline 25 & $\mathrm{~L}$ & 男性 & 23 & 173 & 69 \\
\hline 26 & M & 男性 & 23 & 169 & 75 \\
\hline 27 & $\mathrm{~N}$ & 女性 & 18 & 156 & 56 \\
\hline 28 & $\mathrm{O}$ & 男性 & 18 & 169 & 53 \\
\hline
\end{tabular}

ギー消費量の平均值の相関関係を表す。船舶動摇の 範囲は、前後摇れ（surge）が $0.06 \mathrm{~m} / \mathrm{s}^{2} \sim 0.18 \mathrm{~m} / \mathrm{s}^{2}$ 、 左右摇れ (sway) が $0.11 \mathrm{~m} / \mathrm{s}^{2} \sim 0.33 \mathrm{~m} / \mathrm{s}^{2}$ 、上下摇れ (heave) が $0.39 \mathrm{~m} / \mathrm{s}^{2} \sim 1.38 \mathrm{~m} / \mathrm{s}^{2}$ 、横摇れ (roll) が $0.01 \mathrm{rad} / \mathrm{s} \sim 0.04 \mathrm{rad} / \mathrm{s} 、$ 縦摇れ (pitch) が $0.01 \mathrm{rad} / \mathrm{s}$ $\sim 0.04 \mathrm{rad} / \mathrm{s}$ 、船首摇れ (yaw) が $0.01 \mathrm{rad} / \mathrm{s} \sim 0.04$ $\mathrm{rad} / \mathrm{s}$ であった。図中の $\mathrm{r}$ は相関係数を表す。

本研究では、相関係数による共線性の評価を行っ たところ、相関係数 0.80 以上を相関が高いと判断 することで、重回帰分析の結果に共線性が現れなく なった。これより、本研究では図 4～図8 を考慮し、 共線性を示寸現象が現れなかった相関係数 0.80 を 指標として、2つの独立変数間に 0.80 以上の相関が 確認された場合は、エネルギー消費量との相関が高 い変数を残し、もう一方の変数は除外することで、 独立変数の選択を行った。相関係数 0.80 以上を示 した 2 変数を表 3 に示す。変数の選択の結果、独立
表 3 相関係数 0.80 以上を示した 2 変数

\begin{tabular}{|c|c|c|}
\hline 変数 1 & 変数2 & 相関係数 \\
\hline 上下摇れ(頭部) & 上下摇れ (床) & 0.99 \\
\hline 上下摇れ(腰部) & 上下摇れ (床) & 0.97 \\
\hline 上下摇れ (頭部) & 上下摇れ(腰部) & 0.96 \\
\hline 上下摇れ(腰部) & 縦摇れ （床） & 0.91 \\
\hline 縦摇れ (床) & 上下摇れ (床) & 0.90 \\
\hline 体重 & 身長 & 0.90 \\
\hline 上下摇れ(頭部) & 縦摇れ（床） & 0.89 \\
\hline 縱摇れ（頭部） & 前後摇れ (頭部) & 0.89 \\
\hline 左右摇れ(頭部) & 左右摇れ (床) & 0.87 \\
\hline 縦摇れ (床) & 前後摇れ (床) & 0.86 \\
\hline 縦摇れ （腰部） & 前後摇れ(腰部) & 0.86 \\
\hline 左右摇れ(腰部) & 前後摇れ(腰部) & 0.84 \\
\hline 左右摇れ(頭部) & 左右摇れ(腰部) & 0.83 \\
\hline 船首摇れ(腰部) & 左右摇れ(腰部) & 0.82 \\
\hline 左右摇れ (腰部) & 横摇れ （床） & 0.81 \\
\hline 前後摇れ(腰部) & 縦摇れ （床） & 0.80 \\
\hline 横摇れ （床） & 左右摇れ (床) & 0.80 \\
\hline
\end{tabular}

表 4 重回帰分析に用いた変数

\begin{tabular}{|c|c|c|c|}
\hline \multicolumn{2}{|l|}{ 変数 } & \multicolumn{2}{|r|}{ 値 } \\
\hline 従属変数 & $Y$ & \multicolumn{2}{|c|}{ エネルギー消費量 } \\
\hline \multirow{10}{*}{ 独立変数 } & $X_{1}$ & \multirow{3}{*}{ 頭部 } & 前後摇れ（surge、x軸方向の加速度） \\
\hline & $X_{2}$ & & 横摇れ （roll、 $\mathrm{x}$ 軸まわりの角速度） \\
\hline & $X_{3}$ & & 船首摇れ（yaw、z軸まわりの角速度） \\
\hline & $X_{4}$ & \multirow{4}{*}{ 腰部 } & 左右摇れ（sway、y軸方向の加速度） \\
\hline & $X_{5}$ & & 上下摇れ (heave、z軸方向の加速度) \\
\hline & $X_{6}$ & & 横摇れ （roll、 $\quad x$ 軸まわりの角速度） \\
\hline & $X_{7}$ & & 縱摇れ （pitch、y軸まわりの角速度） \\
\hline & $X_{8}$ & \multirow{2}{*}{$\begin{array}{l}\text { 船舶 } \\
\text { の床 }\end{array}$} & 前後摇れ（surge、x軸方向の加速度） \\
\hline & $X_{9}$ & & 船首摇れ（yaw、z軸まわりの角速度） \\
\hline & $X_{10}$ & 体重 & \\
\hline
\end{tabular}

変数として、表 4 に示寸頭部の前後摇れ（surge）、 横摇れ (rol1)、船首摇れ (yaw)、腰部の左右摇れ (sway)、上下摇れ (heave)、横摇れ (roll)、縦摇 れ (pitch)、小型船舶の床の前後摇れ (surge)、船 首摇れ (yaw)、体重の 10 変数が選択された。個体差 を表す体重と身長の相関係数は 0.90 であったため、 体重に比べてエネルギー消費量との相関が低い身 長を重回帰分析から除外している。決定された重回 帰モデルを式(10)に、重回帰分析により推定される 重回帰モデルを式(11)に示す。

$Y=\beta_{0}+\beta_{1} X_{1}+\beta_{2} X_{2}+\cdots+\beta_{10} X_{10}+\varepsilon$

$\widehat{Y}=b_{0}+b_{1} X_{1}+b_{2} X_{2}+\cdots+b_{10} X_{10}$ 

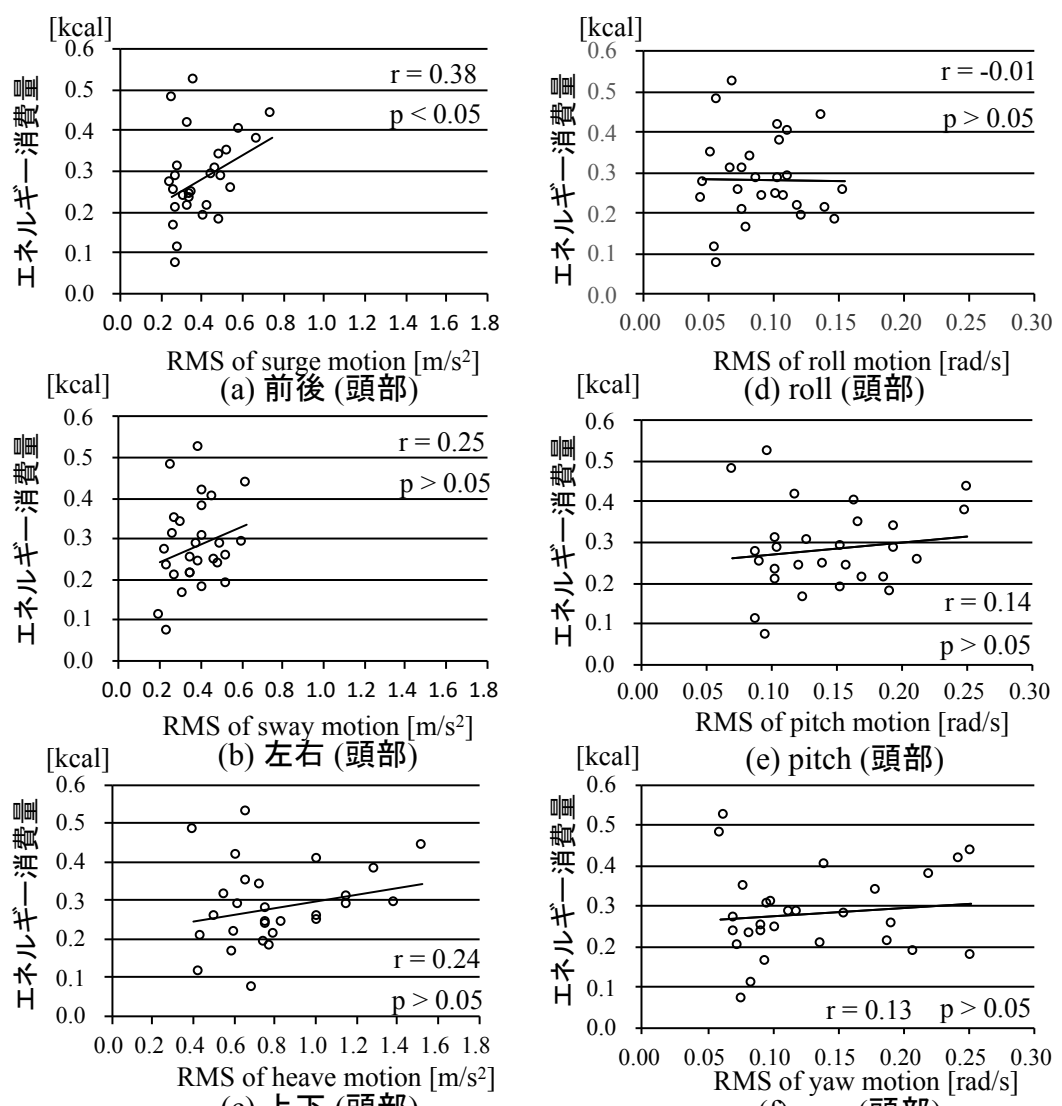

(c) 上下 (頭部)

(f) yaw (頭部)

図 4 実験協力者の頭部で計測された加速度・角速度の実効值とエネルギー消費量の平均值の相関関係
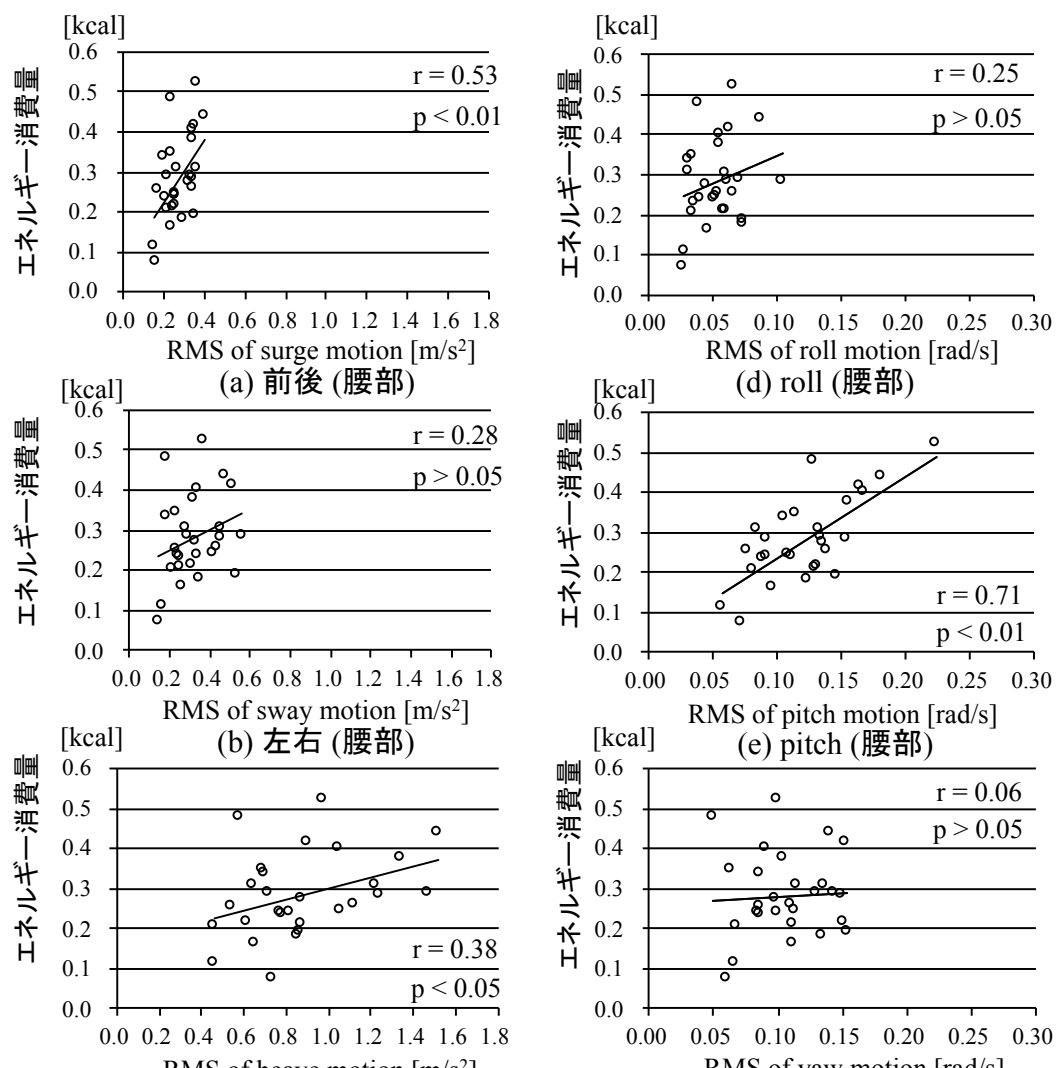

RMS of heave motion $\left[\mathrm{m} / \mathrm{s}^{2}\right]$

(c) 上下 (腰部)

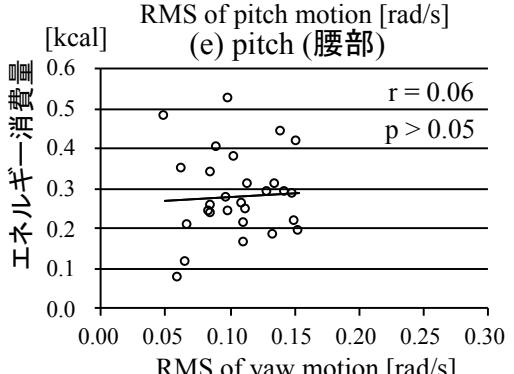

(f) yaw (腰部)

図 5 実験協力者の腰部で計測された加速度・角速度の実効值とエネルギー消費量の平均值の相関関係 

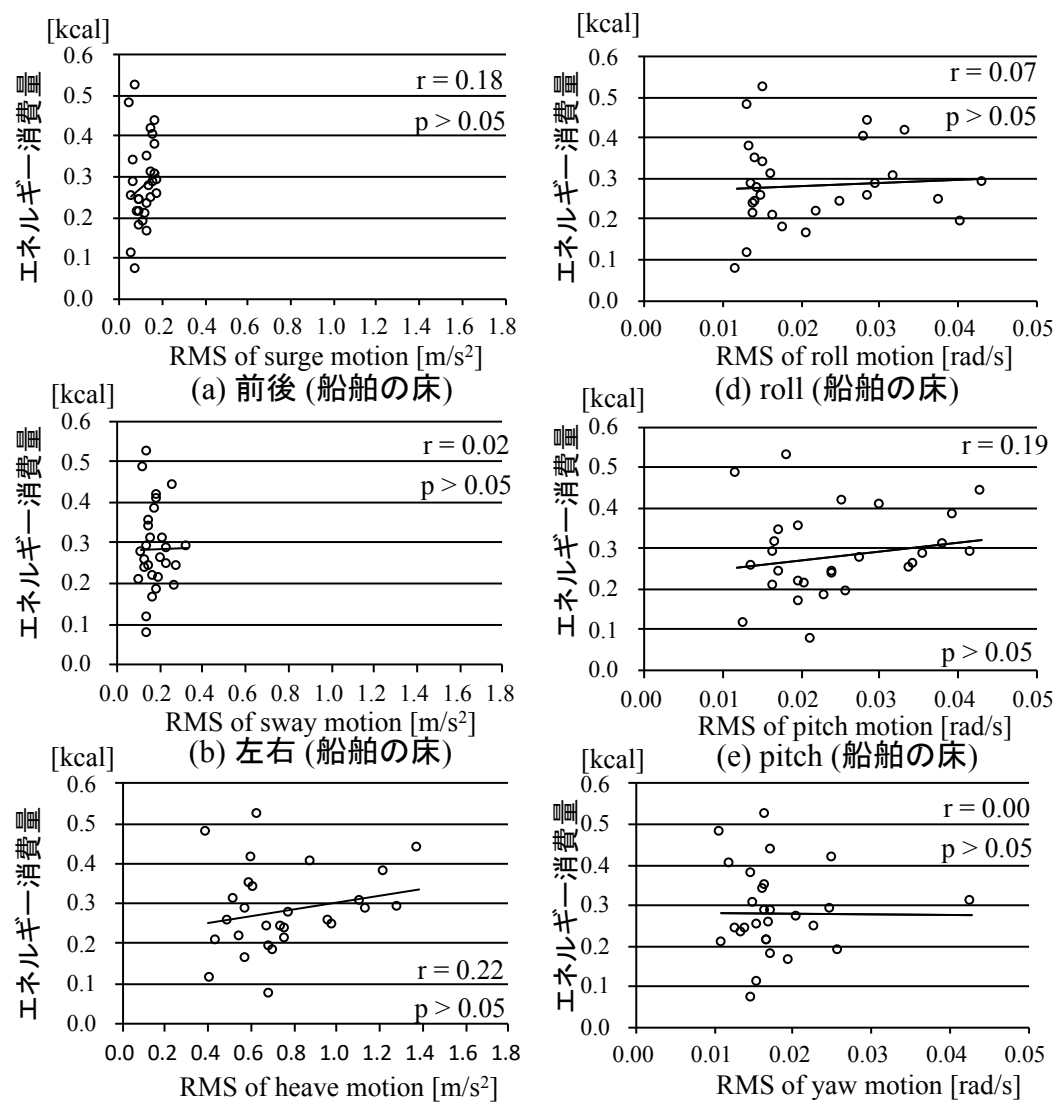

(c) 上下 (船舶の床)

(f) yaw (船舶の床)

図 6 小型船舶の床で計測された加速度・角速度の実効值とエネルギー消費量の平均值の相関関係

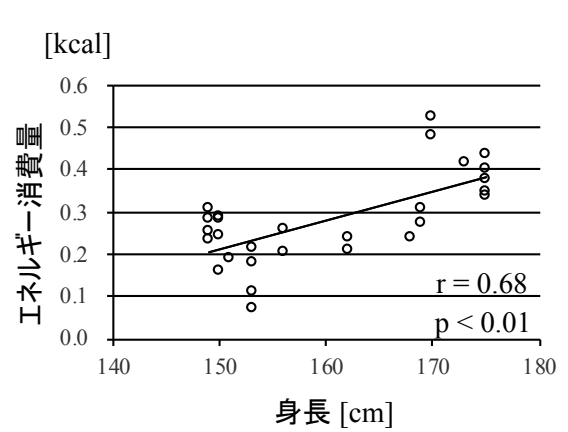

図 7 身長とエネルギー消費量の平均值の相関関係

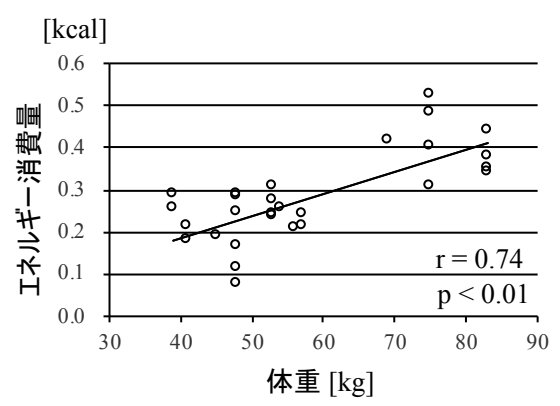

図 8 体重とエネルギー消費量の平均值の相関関係

\section{2 エネルギー消費量に影響を及ぼす因子}

重回帰分析の結果を表 5 に示す。生体のエネルギ 一消費量に影響を及ぼす因子には、腰部の縦摇れ （pitch）と体重が抽出された。標準偏回帰係数は、

表 5 重回帰分析の結果

\begin{tabular}{|c|c|c|c|c|}
\hline \multicolumn{3}{|c|}{ 変数 } & 標準偏回帰係数 & $\mathrm{p}$ 值 \\
\hline \multicolumn{2}{|r|}{ 切片 } & $b_{0}$ & -0.11 & 1.00 \\
\hline \multirow{3}{*}{ 頭部 } & 前後摇れ (surge) & $b_{1}^{\prime}$ & - & 0.10 \\
\hline & 横摇れ （roll） & $b_{2}^{\prime}$ & - & 0.12 \\
\hline & 船首摇れ (yaw) & $b_{3}^{\prime}$ & - & 0.14 \\
\hline \multirow{4}{*}{ 腰部 } & 左右摇れ (sway) & $b_{4}^{\prime}$ & - & 0.77 \\
\hline & 上下摇れ (heave) & $b_{5}^{\prime}$ & - & 0.59 \\
\hline & 横摇れ （roll） & $b_{6}^{\prime}$ & - & 1.00 \\
\hline & 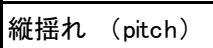 & $b_{7}^{\prime}$ & $0.48^{\mathrm{a})}$ & 0.00 \\
\hline \multirow{2}{*}{ 船舶の床 } & 前後摇れ (surge) & $b_{8}^{\prime}$ & - & 0.37 \\
\hline & 船首摇れ (yaw) & $b_{g^{\prime}}$ & - & 0.99 \\
\hline \multicolumn{2}{|l|}{ 体重 } & $b_{10}^{\prime}$ & $0.53^{\mathrm{b})}$ & 0.00 \\
\hline \multicolumn{3}{|c|}{ 重相関係数 (R) } & \multicolumn{2}{|l|}{$0.84^{c)}$} \\
\hline \multicolumn{3}{|c|}{ 自由度調整済み決定係数 $\left(\mathrm{R}^{2}\right)$} & \multicolumn{2}{|l|}{$0.71^{d)}$} \\
\hline
\end{tabular}

一: 因子として選択されなかった変数 
腰部の縦摇れ（pitch）が 0.48（表 4a）、体重が 0.53

（表 3b）となった。従属变数の予測值と実測值の相 関係数を表す重相関係数は 0.84（表 4c）、重回帰モ デルのあてはまりの良さを意味する自由度調整済 決定係数は 0.71 （表 4d）となった。

\section{4. 考察}

Breidah1 らの研究では、2 隻の漁船を用いて、船 舶の床の回転運動と船員のエネルギー消費量の関 係について直線回帰分析を行っているが、有意な相 関がなかったことが報告されている ${ }^{(4)}$ 。一方、筆者 らの研究ではこれまでに、生体の立位姿勢動摇に着 目し、小型船舶の床、生体の腰部、頭部の動摇の大 きさを加速度・角加速度を指標として評価し、関節 のない棒と比較を行っている ${ }^{\left({ }^{8}\right)}$ 。筆者らの先行研究 では、関節をもつ生体が腰部や頭部の回転方向の動 きで姿勢制御を行う傾向にあることが観察され、船 舶動摇と生体の立位姿勢動摇は異なることが示さ れた。生体が腰部や頭部の回転方向の動きで姿勢制 御を行う傾向にあることは、本論文の図 4〜図 6 の (d)～(f) に示した角速度の分布からも確認できる。 本研究では、小型船舶の床、生体の腰部、頭部の加 速度・角速度とエネルギー消費量の相関関係を分析 することにより、生体の腰部の縦摇れ (pitch) とエ ネルギー消費量に相関 $\mathrm{r}=0.71$ （図 $5(\mathrm{e})$ ) があるこ と、また表 6 に示すように、腰部の縦摇れ (pitch) と船舶動摇の個々の成分との相関は低いことがわ かった。さらに重回帰分析の結果においても、エネ ルギー消費量に影響を及ぼすパラメータとして、腰 部の縦摇れ（pitch）が抽出された。立位姿勢動摇に 起因すると考えられる生体のエネルギー消費量は、 主に腰部の縦摇れ (pitch) の動きにより生じたもの と考えられる。本研究の実験環境においては、生体 の立位姿勢時の肉体的疲労の原因を解明するため には、生体の腰部の縦摇れ (pitch) が重要なパラメ 一タであることがわかった。

本研究で構築した体重と腰部の縦摇れ (pitch) か らなるエネルギー消費量の推定モデルは、自由度調 整済決定係数が 0.71 を示したことから、71\%の一致 が見込まれた。エネルギー消費量の推定モデルの精 度を上げるためには、気温、体温、性差やホルモン などを考慮する必要があるものと考えられる(13), (14)。 また、本研究では実験系を簡単化するために、変針 や旋回などを行わず一定の速度で前進する半滑走 型の小型船舶内で実験を実施した。より実船に近い
表 6 腰部の縦摇れ（pitch）と船舶動摇の相関係数

\begin{tabular}{|l|c|}
\hline \multicolumn{1}{|c|}{ 船舶動摇 } & $\begin{array}{c}\text { 腰部の縦摇れ(pitch) } \\
\text { との相関係数 }\end{array}$ \\
\hline 前後摇れ (surge) & 0.38 \\
\hline 左右摇れ (sway) & 0.37 \\
\hline 上下摇れ (heave) & 0.48 \\
\hline 横摇れ (roll) & 0.39 \\
\hline 縱摇れ (pitch) & 0.50 \\
\hline 船首摇れ (yaw) & -0.01 \\
\hline
\end{tabular}

動摇環境での生体の立位姿勢動摇とエネルギー消 費量の関係を導くことで、エネルギー消費量の予測 モデルの正確性が増すと考えられる。今後、室内に おいて動摇装置 ${ }^{(15)}$ を用いることで、気温などの影響 が少なく再現性のある実験を行い、より精度の高い エネルギー消費量の推定モデルについて検討を行 う。

実験協力者 15 名から得た 31 例のうち外れ值と判 断された 3 例は、他の実験協力者と比べて船舶動摇 が大きく実験環境が異なる 1 例と、腰部又は頭部の 立位姿勢動摇が極端に大きく、他の実験協力者とは 姿勢維持動作の方法が異なる 2 例であった。本研究 では、生体の立位姿勢動摇とエネルギー消費量の関 係を最も単純なモデルとして推定するために、外れ 值と判断されるデータを除いたが、生体の肉体的疲 労と立位姿勢動摇の関係を導くためには、今後は外 れ值と判断された 3 例も含め、実験協力者ごとの姿 勢維持動作の違いも考慮し、立位姿勢動摇とエネル ギー消費量の関係についてさらなる分析が必要と 考えられる。

\section{5. まとめ}

本研究では、船員の肉体的疲労の原因を解明寸る ために、肉体的疲労を生体の運動の負荷の大きさを 表すエネルギー消費量として捉え、船舶動摇により 生じる生体の立位姿勢動摇がエネルギー消費量に 及ぼす影響の解明を目的とし、エネルギー消費量お よび、小型船舶の床、生体の腰部、頭部で計測され た加速度・角速度の実効值、生体の身長、体重を変 数とした重回帰分析を行った。計測実験は、小型船 舶の重心より前方の位置において実験協力者 15 名 に対して行った。本研究は、一定の速度で前進する 半滑走型の小型船舶内で実験を実施した。

加速度・角速度とエネルギー消費量の相関関係及 び重回帰分析の結果、主に生体の腰部の縦摇れ 
（pitch）がエネルギー消費量に影響を及ぼすこと がわかった。本研究の実験環境において、生体の立 位姿勢時の肉体的疲労の原因を解明寸るためには、 生体の腰部の縦摇れ (pitch) が重要なパラメータで あることがわかった。

\section{謝辞}

本研究は、JSPS 科研費 19651075 (2007 年-2009 年)、 公益財団法人長岡技術科学大学技術開発教育研究 振興会による研究助成 (2008 年)、公益財団法人日 本科学協会 笹川科学研究助成 (24-724、2012 年)、 鳥羽商船高等専門学校校長裁量経費 (教育研究活動 支援）、JSPS 科研費 17H02056（2017 年-2019 年）、 JSPS 科研費 $18 K 13951$ (2018 年-2020 年) による援助 を受け行っています。本研究のデータ収集におきま してご協力頂きました鳥羽商船高等専門学校の実 習船および練習船関係者の皆様、商船学科の皆様、 学生の皆様に厚く御礼申し上げます。

\section{参考文献}

(1) 天下井清 : 疲労と海難, 公益社団法人 日本海難 防止協会 海と安全, Vol. 456, pp. 3-10, 1997. 1.

(2) 片岡洋祐：中枢性疲労の動物モデルと睡眠誘導 メカニズム, 別冊・医学のあゆみ 最新・疲労の 科学一日本発: 抗疲労・抗過労一の提言一, pp. 17-21，医歯薬出版株式会社，2010.

(3) 木村暢夫, 甫喜本司, 天下井清: 船体運動が身体 機能に与える影響について一船酔い, 疲労と船 体運動との関係一, 日本航海学会論文集, Vol. 50, pp. 377-385, 1994. 3, (doi:10.9749/jin. 90. 377).

(4) Breidahl T, Christensen M, Jepsen JR, Johansen JP, Omland Ø:The influence of ship movements on the energy expenditure of fishermen: a study during a North Sea voyage in calm weather, International Maritime Health, Vol.64, No. 3, pp.114-120, 2013.

(5)F. B. Horak and L. M. Nashner. Central Programming of Postural Movements: Adaptation to Altered Support-Surface Configurations. Journal of Neurophysiology 1986; 55 (6) : 1369-1381.

(6) Renon Doine, Takanori Sakamaki, Hiroaki Seta, Masamitsu Ito, Akihiko Homma and Yasuhiro Fukui : The Exercise Load of Passengers'
Postural Control Against Ship Motion Using Human Energy Expenditure, Advanced Biomedical Engineering, Vol.4, pp.164-169, 2015. 9, (doi:10. 14326/abe. 4. 164).

（7）土井根礼音, 宮脇富士夫, 坂牧孝規, 瀬田広明: 小型船舶乗船者の立位姿勢動摇が生体のエネ ルギー消費量に及ぼす影響, 日本航海学会第 139 回講演会講演予稿集, Vol. 6, No. 2, pp. 151154, 2018.

（8）土井根礼音, 坂牧孝規, 瀬田広明, 伊藤政光, 本間章彦, 福井康裕 : 船舶動摇に対する乗船者 の立位姿勢動摇の解析, ライフサポート, Vol. 27, No. 2, pp. 45-53, 2015. 6, (doi: 10. 5136/1ifesupport. 27. 45).

(9) アミール・D. アクゼル，ジャヤベル・ソウンデ ルパンディアン：ビジネス統計学 下, pp. 167173，ダイヤモンド社， 2012.

(10) 石村貞夫 : 寸ぐわかる多変量解析, pp. 1-31, 東 京図書株式会社, 2007.

(11) Kazuo Male: Dynamic Characteristic of Human Energy Metabolism Observed from Transition of Walking, Journal of the Anthropological Society of Nippon, Vol.84, No. 3, pp. 221229, 1976, (doi:10.1537/ase1911.84.221).

(12) 伊佐弘, 谷口勝則, 岩井嘉男, 吉村勉, 見市知 昭 : 基礎電気回路, pp. 53-54, 森北出版株式会 社, 2011.

(13) 細谷憲政 : 今なぜエネルギー代謝か, pp. 8-10, 第一出版株式会社，2000.

（14）厚生労働省：食生活改善指導担当者研修「食生 活改善指導担当者テキスト」(5) 運動の基礎科 学, http://www. mhlw. go. jp/bunya/shakaiho sho/iryouseido01/pdf/info03k-06. pdf, 2018. 3.

（15）坂牧孝規, 土井根礼音, 瀬田広明, 小川伸夫 : 小型船舶および動摇装置による動摇に対する 生体の立位姿勢動摇と運動負荷, 日本航海学会 論文集，Vo1.134，pp.98-102，2016. 7, （doi： 10. 9749/jin. 134. 98). 